\title{
ANALISIS MENGENAI PERTANGGUNGJAWABAN PENGEMBANG RUMAH SUSUN TERKAIT KETIADAAN SERTIFIKAT LAIK FUNGSI MENURUT UNDANG-UNDANG NOMOR 20 TAHUN 2011 TENTANG RUMAH SUSUN JUNTO UNDANG-UNDANG NOMOR 28 TAHUN 2002 TENTANG BANGUNAN GEDUNG (STUDI KASUS APARTEMEN PARAMA CILANDAK JAKARTA SELATAN)
}

\author{
Octavianna Evangelista \\ (Mahasiswi Program S1 Fakultas Hukum Universitas Tarumanagara) \\ (E-mail: octasormin96@gmail.com) \\ Hanafi Tanawijaya \\ (Corresponding Author)
}

(Dosen Hukum Agraria Fakultas Hukum Universitas Tarumanagara, Meraih Sarjana Hukum dari

Fakultas Hukum Universitas Tarumanagara, Magister Hukum dari Fakultas Hukum Universitas

Tarumanagara)

(E-mail: hanafitanawijaya@gmail.com)

\begin{abstract}
Building Worthiness Certificate is the certificate given by the Regional Government to those buildings that are completely built and already fulfilled all the requirements such as Technical and Administrative Requirements. Building Worthiness Certificate is the evidence to prove that the building is worth on the function. Building Worthiness Certificate is the government's effort to put the safety aspects on the first priority.Based on the Law of the Republic of Indonesia Number 28 of 2002 concerning Buildings, it says the Building Worthiness Certificate must be owned by the developers, with no exceptions to an apartment as it is stated in the Law of The Republic of Indonesia Number 20 of 2011 concerning apartments.Building Worthiness Certificate will be published if all the parameters of the worthiness has been satisfied such as safety, health, comfort and convenience aspects. In fact, the act of the developer has violated the laws. As a result of that, the building of the apartment was on fire. The purpose of this study is to determine the responsibility of the developer as it is the consequence of violating the laws.
\end{abstract}

Keywords : Apartments, Building Worthiness Certificate 


\section{Pendahuluan}

\section{A. Latar Belakang}

Deklarasi Universal Hak Asasi Manusia yang diselenggarakan pada tanggal 10 Desember 1948 merupakan tonggak sejarah dari semangat kemerdekaan, keadilan dan peradaban dunia serta semangat kemanusiaan. Jauh sebelum Deklarasi Universal Hak Asasi Manusia tersebut, Indonesia sudah mengesahkan Undang-Undang Dasar 1945 yang di mana salah satu bagian dari Deklarasi Universal Hak Asasi Manusia ialah untuk mengatur tentang hak setiap orang atas standar kehidupan yang memadai, termasuk tempat tinggal. Ketentuan yang sama tentang hal ini diatur dalam UndangUndang Dasar 1945 di dalam Pasal 28 H ayat (1) Undang-Undang Dasar 1945 menyatakan bahwa "setiap orang berhak hidup sejahtera lahir dan batin, bertempat tinggal, dan mendapatkan lingkungan hidup yang baik dan sehat serta berhak memperoleh pelayanan kesehatan”. Komitmen pemerintah Indonesia dalam memenuhi hak setiap warga negara Indonesia mempunyai tempat tinggal tersebut diwujudkan dengan diundangkannya beberapa peraturan perundang-undangan tentang perumahan.

Rumah menurut Kamus Besar Bahasa Indonesia diartikan sebagai "bangunan untuk tempat tinggal, bangunan pada umumnya (seperti gedung)". 1) Menurut Undang-Undang Nomor 28 Tahun 2002 tentang Bangunan Gedung yang dimaksud dengan bangunan gedung adalah wujud fisik hasil pekerjaan konstruksi yang menyatu dengan tempat kedudukannya, sebagian atau seluruhnya berada di atas dan/atau di dalam tanah dan/atau air, yang berfungsi sebagai tempat manusia melakukan kegiatannya, baik untuk hunian atau tempat tinggal, kegiatan keagamaan, kegiatan usaha, kegiatan sosial, budaya, maupun kegiatan khusus.Bangunan gedung diselenggarakan berlandaskan asas kemanfaatan, keselamatan, keseimbangan, dan harmonisasi dengan lingkungannya. Pengaturan bangunan gedung bertujuan untuk:

\footnotetext{
1) Departemen Pendidikan Nasional, Kamus Besar Bahasa Indonesia, (Jakarta: PT Gramedia Pustaka Utama, 2012), 1188
} 
1. Mewujudkan bangunan gedung yang fungsional serta memiliki tata bangunan gedung yang serasi dan selaras dengan lingkungannya;

2. Mewujudkan ketertiban dalam penyelenggaraan bangunan gedung agar terjamin keandalan teknisnya, mulai dari segi keselamatan, kesehatan, kenyamanan, dan kemudahan;

3. Mewujudkan kepastian hukum dalam penyelenggaraan bangunan gedung.

Undang-Undang Nomor 28 Tahun 2002 tentang Bangunan Gedung tersebut mengatur ketentuan-ketentuan pokok mengenai bangunan gedung. Dijelaskan di dalam undang-undang tersebut bahwa suatu bangunan harus memenuhi beberapa persyaratan diantara lain :

1. Persyaratan administratif, yaitu persyaratan berbentuk perizinan yang diperlukan sebagai syarat untuk melakukan pembangunan rumah susun. Perizinan tersebut berupa status hak atas tanah dan Izin Mendirikan Bangunan (IMB);

2. Persyaratan teknis, yaitu persyaratan peruntukan lokasi serta intensitas dan arsitektur bangunan dan persyaratan keandalan bangunan yang meliputi persyaratan keselamatan, kesehatan, kenyamanan dan kemudahan.

3. Persyaratan ekologis, yaitu persyaratan yang memenuhi analisis dampak lingkungan dalam hal pembangunan rumah susun.

Selain itu, Undang-Undang Nomor 28 Tahun 2002 tentang Bangunan Gedung, yang merupakan induk dari seluruh peraturan mengenai bangunan gedung, mewajibkan seluruh bangunan harus dilengkapi dengan Sertifikat Laik Fungsi yang dikeluarkan oleh bupati/walikota setempat setelah dilakukan pemeriksaan dan pengujian terhadap persyaratan administratif dan persyaratan teknis suatu rumah susun. Sertifikat Laik Fungsi tersebut menjadi suatu surat keterangan tertulis yang dapat dijadikan suatu bukti terhadap kelaikan suatu bangunan. Sertifikat Laik Fungsi tersebut berfungsi untuk memberikan rasa aman terhadap penghuni satuan unit rumah susun oleh karena satuan unit rumah susun miliknya telah dinyatakan laik untuk difungsikan sebagai tempat tinggal.Adapun parameter untuk mengukur bahwa 
bangunan tersebut dapat dinyatakan laik fungsi yaitu jika bangunan tersebut telah memenuhi persyaratan-persyaratan sebagai berikut $:^{2)}$

1. Keselamatan

Bangunan memiliki tingkat keselamatan bagi penghuni dan lingkungannya, di mana yang menjadi persyaratan keselamatan adalah kemampuan bangunan gedung untuk mendukung beban muatan. Tolak ukurnya adalah struktur yang stabil dan kukuh dalam mendukung beban muatan tersebut sampai dengan kondisi pembebanan maksimum dan variasi pembebanan, baik beban muatan hidup maupun beban muatan mati. Hal ini bertujuan agar bila terjadi keruntuhan, pengguna bangunan gedung masih dapat menyelamatkan diri. Untuk daerah/zona tertentu, strukur juga harus mendukung beban muatan yang timbul akibat perilaku alam. Ketentuan mengenai pembebanan, ketahanan terhadap gempa bumi, dan/atau angin mengacu kepada SNI mengenai Peraturan Muatan Indonesia. Daftar SNI yang menyangkut struktur diantaranya sebagai berikut.

a. SNI 03-1727-1989, tentang tata cara pembebanan untuk rumah dan gedung;

b. SNI 03-1728-1989, tentang tata cara pelaksanaan mendirikan bangunan gedung;

c. SNI 03-2397-1991, tentang tata cara perencanaan rumah sederhana tahan angin;

d. SNI 03-1729-2002, tentang tata cara perencanaan struktur baja untuk bangunan gedung;

e. SNI 03-1734-1989, tentang tata cara perencanaan beton bertulang dan struktur dinding bertulang untuk rumah dan gedung;

f. SNI 03-2847-1992, tentang tata cara perhitungan beton untuk bangunan gedung;

\footnotetext{
${ }^{2)}$ Arief Sabaruddin, A-Z Persyaratan Teknis Bangunan, (Jakarta: Griya Kreasi, 2013), 102
} 
g. SNI 03-1726-2002, tentang tata cara perencanaan ketahanan gempa untuk bangunan dan gedung;

h. RSNI T-02-2003, tentang tata cara perencanaan konstruksi kayu Indonesia;

i. Pt-T-31-2000-C, tentang tata cara perbaikan struktur beton bertulang akibat kerusakan atau keropos dengan beton agregat prepak.

Persyaratan yang kedua adalah kemampuan bangunan gedung dalam mencegah dan menanggulangi bahaya kebakaran, melalui sistem proteksi pasif dan/atau proteksi aktif. Sistem proteksi pasif meliputi kemampuan stabilitas struktur dan elemennya. Material konstruksi yang tahan api, kompartemenisasi dan pemisahan, serta proteksi pada bukaan yang ada untuk menahan dan membatasi kecepatan menjalarnya api dan asap kebakaran. Sementara sistem proteksi aktif meliputi kemampuan peralatan dalam mendeteksi dan memadamkan kebakaran, pengendalian asap, dan sarana penyelamatan kebakaran. Kedua sistem tersebut wajib ada pada semua bangunan, kecuali pada bangunan rumah tinggal. Selanjutnya ketentuan tersebut diatur dalam SNI tentang proteksi kebakaran untuk bangunan gedung. Persyaratan ketiga yakni persyaratan kemampuan bangunan gedung dalam mencegah bahaya petir melalui sistem penangkal petir. Sistem penangkal petir pada suatu bangunan gedung harus mampu melindungi semua bagian gedung tersebut, termasuk penghuni di dalamnya. Instalasi penangkal petir umumnya dipengaruhi oleh letak, sifat geografis, bentuk dan fungsi bangunan tersebut.

2. Kesehatan

Bangunan memiliki tingkat kesehatan yang baik bagi penghuni dan lingkungannya. Persyaratan kesehatan bangunan gedung meliputi persyaratan sistem penghawaan, pencahayaan, sanitasi, dan penggunaan bahan bangunan gedung. Sistem penghawaan mengakomodisasi kebutuhan sirkulasi dan pertukaran udara yang harus disediakan pada bangunan gedung 
melalui bukaan, dan.atau ventilasi alami, dan/atau ventilasi buatan. Sistem pencahayaan juga harus dapat memenuhi kebutuhan pencahayaan yang harus disediakan pada bangunan gedung, baik melalui pencahayaan alami maupun pencahayaan buatan, termasuk pencahayaan darurat. Bangunan gedung tempat tinggal, pelayanan kesehatan, pendidikan, dan bangunan pelayanan umum lainnya harus mempunyai bukaan untuk pencahayaan alami. Untuk mendapatkannya, harus dilakukan studi orientasi bangunan terhadap sinar matahari sebelum mulai mendesain bangunan tersebut. Sistem sanitasi harus disediakan di dalam dan di luar bangunan gedung. sistem ini bertujuan untuk memenuhi kebutuhan air bersih, pembuangan air kotor dan/atau air limbah, kotoran dan sampah, serta penyaluran air hujan. Sistem sanitasi ini sebaiknya mudah dalam pengoperasian dan pemeliharaannya, tidak membahayakan, serta tidak mengganggu lingkungan. Penggunaan bahan bangunan gedung juga harus aman bagi kesehatan pengguna bangunan gedung dan tidak menimbulkan dampak negatif terhadap lingkungan.

\section{Kenyamanan}

Bangunan memiliki tingkat kenyamanan bagi penghuni dan lingkungannya. Persyaratan kenyamanan bangunan gedung meliputi kenyamanan ruang gerak dan hubungan antarruang, kondisi udara dalam ruang, pandangan, serta tingkat getaran dan tingkat kebisingan. Kenyamanan ruang gerak diperoleh dari dimensi ruang yang cukup serta tata letak ruang yang baik dan sesuai fungsi sehingga memberikan kenyamanan bergerak dalam ruangan. Kenyamanan hubungan antarruang berhubungan dengan tata letak ruang dan sirkulasi antarruang di dalam bangunan gedung. Desain ruangan yang fungsional merupakan kunci untuk mendapatkan sirkulasi yang baik sehingga tercipta pola aktivitas penghuni yang nyaman. Kenyamanan kondisi udara dalam ruang merupakan tingkat kenyamanan yang diperoleh dari temperatur dan kelembapan di dalam ruang. Kenyamanan pandangan merupakan suatu kondisi terpenuhinya hak pribadi setiap orang dalam 
melaksanakan kegiatannya di dalam bangunan gedung, tanpa terganggu kegiatan bangunan gedung lain di sekitarnya. Kenyamanan tingkat getaran dan kebisingan merupakan tingkat kenyamanan yang ditentukan oleh suatu keadaan tidak terganggunya pengguna dan fungsi bangunan gedung oleh getaran atau kebisingan yang timbul baik dari dalam bangunan gedung maupun lingkungannya.

4. Kemudahan

Bangunan memberikan kemudahan bagi seluruh penggunanya. Persyaratan kemudahan merupakan kemudahan hubungan ke, dari, dan di dalam bangunan gedung, serta kelengkapan sarana dan prasarana dalam pemanfaatan bangunan gedung. Kemudahan tersebut meliputi tersedianya fasilitas dan aksesibilitas yang mudah dan nyaman termasuk bagi penyandang cacat dan lanjut usia. Pada bangunan gedung untuk kepentingan umum, kelengkapan prasarana dan saranannya lebih luas lagi, di antaranya penyediaan fasilitas yang cukup untuk ruang ibadah, ruang ganti, ruangan bayi, toilet, tempat parkir, tempat sampah, serta fasilitas komunikasi dan informasi.

Salah satu jenis dari bangunan gedung ialah rumah susun, maka dari itu Undang-Undang Nomor 20 Tahun 2011 tentang Rumah Susun merupakan cerminan dari Undang-Undang Nomor 28 Tahun 2002 tentang Bangunan Gedung.Rumah susun tersebut memiliki nilai yang lebih ekonomis dan dapat dijangkau oleh semua kalangan, jika dibandingkan dengan rumah tapak. Oleh karena itu pembangunan rumah susun berkembang pesat guna memenuhi kebutuhan tempat tinggal masyarakat.

Pengertian rumah susun tertuang di dalam Pasal 1 angka 1 Undang-Undang Nomor 20 Tahun 2011 tentang Rumah Susun di mana dikatakan rumah susun sebagai "bangunan gedung bertingkat yang dibangun dalam suatu lingkungan, terbagi dalam bagian-bagian yang distrukturkan secara fungsional dalam arah horisontal maupun vertikal dan merupakan satuan-satuan yang masing-masing dapat dimiliki dan 
digunakan secara terpisah, terutama untuk tempat hunian, yang dilengkapi dengan Bagian Bersama, Benda Bersama dan Tanah Bersama”.Bagian bersama sebagaimana disebutkan di dalam Pasal 1 angka 1 Undang-Undang Nomor 20 Tahun 2011 tentang Rumah Susun merupakan bagian-bagian dari rumah susun yang dimiliki bersama secara tidak terpisah oleh semua pemilik satuan unit rumah susun dan diperuntukkan pemakaian bersama, seperti lift, tangga, lorong, pondasi, atap bangunan, ruang untuk umum dan lainnya. ${ }^{3)}$ Benda bersama ialah benda-benda dan bangunan-bangunan yang bukan merupakan bagian dari bangunan gedung rumah susun yang bersangkutan, tetapi berada di atas "tanah-bersama" dan diperuntukkan bagi pemakaian bersama. Seperti bangunan tempat ibadah, lapangan parkir, olahraga, pertamanan, tempat bermain anak-anak, dan lainnya. Benda-benda dan bangunan-bangunan tersebut juga merupakan milik-bersama yang tidak terpisah dari semua pemilik satuan unit rumah susun. ${ }^{4)}$ Tanah bersama adalah sebidang tanah tertentu di atas mana banunan rumah susun yang bersangkutan berdiri, yang sudah pasti status hak, batas-batas dan luasnya. Tanah tersebut bukan milik para pemilik satuan unit rumah susun yang ada di lantai dasar, melainkan seperti halnya bagian bersama, juga merupakan hakbersama semua pemilik satuan unit rumah susun dalam bangunan rumah susun yang bersangkutan.

Selain itu, bangunan rumah susun juga terdiri dari Prasarana, Sarana, dan Utilitas Umum. Prasarana adalah kelengkapan dasar fisik lingkungan hunian rumah susun yang memenuhi standar tertentu untuk memenuhi kebutuhan tempat tinggal yang laik, sehat, aman, dan nyaman meliputi jaringan jalan, drainase, sanitasi, air bersih, dan tempat sampah. ${ }^{5)}$ Selain Prasarana, pelaku pembangunan rumah susun (pengembang) wajib melengkapi lingkungan rumah susun dengan sarana yaitu fasilitas yang berfungsi untuk mendukung penyelenggaraan dan pengembangan kehidupan sosial, budaya, dan ekonomi meliputi sarana sosial ekonomi seperti

\footnotetext{
3 ) Boedi Harsono, Hukum Agraria Indonesia, (Jakarta: Djambatan, 2003), 350

4) loc.cit.

5) Urip Santoso, Op. Cit., 417
} 
pendidikan, kesehatan, peribadatan dan perniagaan, dan sarana umum seperti ruang terbuka hijau, tempat rekreasi, sarana olahraga, dan lain-lain. ${ }^{6)}$ Lalu pelaku pembangunan rumah susun (pengembang) wajib pula melengkapi lingkungan rumah susunnya dengan utilitas umum, yaitu kelengkapan penunjang untuk pelayanan lingkungan hunian rumah susun yang mencakup jaringan listrik, jaringan telepon, dan jaringan gas.

Seperti yang sudah disinggung sebelumnya, tujuan dari pembangunan rumah susun yaitu untuk memenuhi kebutuhan perumahan yang layak bagi rakyat terutama golongan masyarakat yang berpenghasilan rendah, yang menjamin kepastian hukum dalam pemanfaatannya. Selain itu pembangunan rumah susun bertujuan untuk meningkatkan daya guna dan hasil guna tanah di daerah perkotaan dengan memperhatikan kelestarian sumber daya alam dan menciptakan lingkungan permukiman yang lengkap, serasi dan seimbang. Pembangunan rumah susun dapat juga untuk memenuhi kebutuhan untuk kepentingan lainnya yang berguna bagi kehidupan masyarakat, yang dalam arti rumah susun bukan hunian. ${ }^{7)}$ Rumah susun tersebut memiliki beberapa jenis sebagaimana yang telah dijelaskan oleh UndangUndang Nomor 20 Tahun 2011 tentang Rumah Susun di mana ditetapkan empat jenis rumah susun, yaitu:

\section{Rumah Susun Umum}

Rumah susun umum adalah rumah susun yang diselenggarakan untuk memenuhi kebutuhan rumah bagi masyarakat berpenghasilan rendah

2. Rumah Susun Khusus

Rumah susun khusus adalah rumah susun yang diselenggarakan untuk memenuhi kebutuhan khusus

3. Rumah Susun Negara

\footnotetext{
6) Loc.cit.

7) Adrian Sutedi, Hukum Rumah Susun\&Apartemen, (Jakarta: Sinar Grafika, 2012), 161
} 
Rumah susun negara adalah rumah susun yang dimiliki oleh negara dan berfungsi sebagai tempat tinggal atau hunian, sarana pembinaan keluarga, serta penunjang pelaksanaan tugas pejabat dan/atau pegawai negeri

\section{Rumah Susun Komersial}

Rumah susun komersial adalah rumah susun yang diselenggarakan untuk mendapatkan keuntungan

Kepemilikan rumah susun pada umumnya terjadi karena adanya jual beli antara penjual/pengembang dengan pembeli/konsumen. Saat ini telah berkembang suatu kebiasaan di dunia properti adalah jual beli dengan sistem inden untuk memasarkan satuan rumah susun yang sedang dibangun bahkan yang belum dibangun di mana penjual/pengembang menjual hanya dengan menunjukkan gambar/denah rumah susun dan belum ada tanda-tanda fisik dari aktivitas pembangunan di lokasi bahkan tidak jarang terjadi pada saat masih direncanakan dan masih belum jelas lokasi tepatnya dimana. Dengan kondisi tersebut tentu saja transaksi secara jual beli tidak mungkin dilakukan. Akta Jual Beli tidak dapat dibuat sebab pada umumnya Akta Jual Beli dilakukan apabila rumah susun telah selesai dibangun atau paling tidak sudah pada tahap penyelesaian akhir (finishing). Oleh karena itu, maka dibuatkanlah suatu Perjanjian Pengikatan Jual beli.Perjanjian Pengikatan Jual Beli adalah perjanjian yang berisikan hak-hak dan kewajiban-kewajiban antara penjual/pengembang dan pembeli/konsumen. ${ }^{8)}$ Perjanjian Pengikatan Jual Beli umumnya merupakan akta perjanjian yang disusun secara sepihak oleh penjual/pengembang di mana perjanjian tersebut bersifat bakukarena berisikan klausula-klausula menurut pihak penjual/pengembang. Perjanjian Pengikatan Jual Beli tersebut tunduk pada ketentuan Undang-Undang Nomor 1 Tahun 2011 tentang Perumahan dan Kawasan Permukiman, di mana tertulis di dalam Pasal 42 ayat (1) Undang-Undang Nomor 1 Tahun 2011 tentang Perumahan dan Kawasan Permukiman menjelaskan bahwa rumah tunggal, rumah deret, dan/atau rumah susun yang masih dalam tahap proses

8) Anonim, "Hak dan Kewajiban Para Pihak dalam Transaksi Rumah Susun (Bagian 1)", www.erwinkallonews.com, diakses tanggal 4 April 2018. 
pembangunan dapat dipasarkan melalui sistem perjanjian pendahuluan jual beli sesuai dengan ketentuan peraturan perundang-undangan. Perjanjian Pengikatan Jual Beli tersebut kemudian diatur lebih lanjut di dalam Keputusan Menteri Perumahan Rakyat Nomor 09/KPTS/M/1995 tentang Pedoman Pengikatan Jual Beli. ${ }^{9)}$

Di dalam Perjanjian Pengikatan Jual Beli tercantum persyaratan-persyaratan yang harus dipenuhi oleh pengembang, dimana salah satunya ialah persyaratan adanya Sertifikat Laik Fungsi. Seperti yang sudah dijelaskan di atas, rumah susun tersebut harus dilengkapi dengan Sertifikat Laik Fungsi terlebih dahulu sebelum pemanfaatannya, dimana Sertifikat Laik Fungsi tersebut dikeluarkan oleh bupati/walikota setempat setelah dilakukan pemeriksaan dan pengujian terhadap persyaratan administratif dan persyaratan teknis. Kenyataannya, banyak sekali pengembang-pengembang yang memanfaatkanbangunan gedungnya dengan tidak adanya Sertifikat Laik Fungsi, salah satunya pengembang dari Apartemen Parama.

Kasus tersebut berawal dari peringatan berupa penyegelan yang dilayangkan oleh Dinas Tata Kota DKI Jakarta pada bulan Maret 2016. Terjadinya penyegelan tersebut dikarenakan Sertifikat Laik Fungsi belum dikeluarkan oleh Badan Pelayanan Terpadu Satu Pintu (BPTSP) DKI Jakarta. Namun penyegelan tersebut tidak diindahkan oleh pihak Apartemen Parama, sehingga hal itu berujung kepada terbakarnya apartemen tersebut pada tanggal 14 Agustus 2016.

Kebakaran tersebut terjadi disebabkan adanya korsleting pada panel listrik utama yang berada di tangga darurat lantai 3. Di saat apartemen terbakar, alarm kebakaran tidak berbunyi sehingga membuat penghuni satuan rumah susun tidak meyakini bahwa kebakaran sedang terjadi. Tidak hanya alarm kebakaran yang tidak berfungsi, tetapi alat pemadam api ringan juga tidak dapat difungsikan. Selain itu, diketahui bahwa perangkat kelistrikan Apartemen Parama merupakan produk lama yang sudah tidak dipakai untuk masa sekarang.

9) Samuel Christian, "Pedoman Pengikatan Jual Beli Rumah, Berdasarkan KEPMENPERA Nomor 09/KPTS/M/1995 Tahun 1995", www.hukumproperti.com, diakses tanggal 4April 2018. 
Pada saat melakukan evakuasi, seluruh penghuni tersebut dituntun ke lantai dasar gedung dengan menggunakan tangga darurat, dimana tangga darurat tersebut telah dipenuhi dengan asap tebal. Proses evakuasi tersebut semakin sulit dilakukan karena lampu penerangan di dalam apartemen tersebut tidak menyala sebab tidak adanya arus listrik.

Diketahui 75 penghuni yang terjebak di dalam satuan unit rumah susun, 18 penghuni diantaranya dilarikan ke rumah sakit terdekat untuk dirawat di Unit Gawat Darurat (UGD) dan Intensive Care Unit (ICU), lantaran mengalami sesak nafas yang disebabkan terlalu banyak menghirup asap tebal. Sebanyak 12 penghuni dirawat di rumah sakit Pondok Indah, 5 penghuni dirawat di rumah sakit Siloam Cilandak, dan 1 penghuni dirawat di rumah sakit Fatmawati.

Setelah diteliti lebih lanjut, ketiadaan Sertifikat Laik Fungsi dikarenakan Apartemen Parama tersebut tidak memiliki Sertifikat Keselamatan Kebakaran yang masih hidup, di mana sertifikat tersebut merupakan salah satu persyaratan dalam pengurusan Sertifikat Laik Fungsi, sebagaimana dikatakan di dalam Pasal 50 Peraturan Daerah DKI Jakarta Nomor 8 Tahun 2008 tentang pencegahan dan penanggulangan bahaya kebakaran.

Dibalik adanya kejadian ini, tidak ada korban meninggal akibat terbakarnya apartemen tersebut, dan tidak ada satuan unit rumah susun yang ikut terbakar. Namunterdapat kerugian materil yang diderita yaitu uang sewa yang telah dibayar dimuka dan biaya rumah sakit semasa perawatan.

Berdasarkan hal tersebut, penulis akan melakukan penelitan dengan judul "ANALISIS MENGENAI PERTANGGUNGJAWABAN PENGEMBANG RUMAH SUSUN TERKAIT KETIADAAN SERTIFIKAT LAIK FUNGSI MENURUT UNDANG-UNDANG NOMOR 20 TAHUN 2011 TENTANG RUMAH SUSUN JUNTO UNDANG-UNDANG NOMOR 28 TAHUN 2002 TENTANG BANGUNAN GEDUNG (STUDI KASUS APARTEMEN PARAMA CILANDAK JAKARTA SELATAN)"• 


\section{B. Perumusan Masalah}

Berdasarkan latar belakang yang telah disajikan di awal, untuk mempertajam fokus dari penelitian ini, maka dirumuskan masalah ke dalam suatu pertanyaan, yaitu bagaimanakah pertanggungjawaban pengembang rumah sususn terkait ketiadaan Sertifikat Laik Fungsi menurut Undang-Undang Nomor 20 Tahun 2011 tentang Rumah Susun Junto Undang-Undang Nomor 28 Tahun 2002 tentang Bangunan Gedung?

\section{Pembahasan}

Menurut Kamus Besar Bahasa Indonesia (KBBI) tanggung jawab adalah keadaan yang mewajibkan seseorang untuk menanggung segala sesuatunya jika terjadi sesuatu hal yang dapat dituntut, dipersalahkan, dan diperkarakan. Di dalam kamus hukum, tanggung jawab diartikan sebagai suatu keharusan bagi seseorang untuk melaksanakan apa yang telah diwajibkan kepadanya.

Secara umum, teori tanggung jawab dibedakan berdasarkan prinsipnya. Berikut merupakan perbedaan dari teori tanggung jawab yang harus diperhatikan oleh pengembang dari Apartemen Parama, yaitu:

\section{Teori Tanggung Jawab Berdasarkan Kesalahan (liability based on fault)}

Teori tanggung jawab ini melihat adanya kesalahan yang telah dilakukan. Seseorang dapat dibebankan pertanggungjawabannya jika di dalam perbuatannya tersebut terdapat unsur kesalahan. Di dalam Pasal 1365 Kitab Undang-Undang Hukum Perdata mengatur mengenai Perbuatan Melawan Hukum (onrechtmatige daad). suatu perbuatan dapat dinyatakan sebagai suatu perbuatan yang melawan hukum jika memenuhi unsur-unsur pokok, yaitu adanya perbuatan, adanya kesalahan, adanya kerugian yang diderita, dan adanya hal yang bertentangan dengan hukum. Hal mengenai kerugian yang dimaksud dijelaskan lebih lanjut di dalam Pasal 1366 Kitab Undang- 
Undang Hukum Perdata, dimana dijelaskan bahwa seseorang tersebut tidak hanya bertanggungjawab terhadap kerugian yang disebabkan oleh perbuatanperbuatannya, melainkan juga bertanggungjawab terhadap kelalaian dan kesembronoannya. Selain itu berdasarkan Pasal 1367 Kitab Undang-Undang Hukum Perdata mengatakan bahwa seseorang tersebut juga bertanggungjawab terhadap kerugian yang disebabkan oleh seseorang lainnya yang menjadi tanggungannya atau disebabkan oleh barang-barang yang berada di bawah pengawasannya.

2. Prinsip Praduga Selalu Bertanggung jawab (Presumption of Liability)

Prinsip yang mengatakan bahwa tergugat selalu dianggap bertanggung jawab sampai ia dapat membuktikan sebaliknya yaitu membuktikan bahwa ia tidak bersalah.

3. Prinsip Praduga Selalu Tidak Bertanggung Jawab (Presumption of NonLiability)

Prinsip tanggung jawab ini mengatakan bahwa tergugat dibebaskan dari segala tanggung jawab sampai ia dibuktikan bahwa tergugat bersalah.

4. Tanggung Jawab Mutlak (Strict Liability)

Prinsip yang menetapkan pelaku untuk bertanggung jawab secara mutlak terhadap hal-hal yang telah merugikan orang lain tanpa harus membuktikan adanya unsur-unsur dari kesalahan pelaku tersebut. Unsur-unsur kesalahan tersebut bukan lah sebagai faktor penentu dari pertanggungjawaban.

\section{Tanggung Jawab dengan Pembatasan (Limitation of Liability)}

Prinsip ini dicantumkan sebagai klausul eksonerasi dalam perjanjian standar yang dibuat oleh pelaku usaha. Prinsip tanggung jawab ini dapat juga dikombinasikan dengan prinsip tanggung jawab lainnya.

Berdasarkan penjelasan mengenai berbagai teori tanggung jawab, penulis menilai teori pertanggungjawaban atas dasar kesalahan (liability based on fault) yang mempunyai relevansi kuat terhadap kasus yang sedang diangkat. Adapun bentuk kesalahan dari PT. Mahakam Indomakmur selaku pengembang Apartemen Parama 
tersebut ialah tidak dipenuhinya kewajiban yang seharusnya dilakukan terkait persyaratan dan perizinan, sebagaimana telah diatur oleh undang-undang.

Di dalam Pasal 37 ayat (1) Undang-Undang Nomor 28 Tahun 2002 tentang Bangunan Gedung, yang kemudian dituangkan juga ke dalam Pasal 39 UndangUndang Nomor 20 Tahun 2011 tentang Rumah Susun, mengatakan bahwa pemanfaatan gedung dapat dilakukan setelah gedung tersebut dilengkapi dengan Sertifikat Laik Fungsi. Hal ini berarti undang-undang mewajibkan PT. Mahakam Indomakmur untuk melengkapi bangunan rumah susunnya dengan Sertifikat Laik Fungsi sebelum bangunan rumah susun tersebut digunakan.

Pengembang dalam hal memohonkan agar penerbitan Sertifikat Laik Fungsi dapat dilakukan, maka pengembang harus memenuhi berbagai macam persyaratan, yaitu Akta Pendirian, Surat Keputusan Pengesahan Pendirian dan Perubahan, bukti kepemilikan tanah, dan Perizinan lain yang terkait seperti rekomendasi terkait Sertifikat Laik Fungsi dari Dinas Cipta Karya, Tata Ruang dan Pertanahan, Sertifikat Laik Operasi Pembangkitan dan Jaringan Distribusi Tenaga Listrik (Genset) dari Dinas Perindustian dan Energi, Perizinan dari Dinas Penanggulangan Kebakaran dan Penyelamatan yaitu Pengesahan Pemakaian Proteksi Kebakaran danSertifikat Keselamatan Kebakaran, Perizinan dari Dinas Tenaga Kerja dan Transmigrasi di antaranya ialah Pengesahan Pemakaian Pesawat Tenaga Produksi, Pengesahan Pemakaian Bejana Tekan, Pengesahan Pemakaian Instalasi Penyalur Petir, Pengesahan Pemakaian Pesawat Angkat dan Angkut (Lift, Eskalator, Gondola), Pengesahan Pemakaian Instalasi Listrik, Pengesahan Pemakaian Pesawat Uap, Berita Acara Hasil Pemeriksaan dan Pengujian Keamanan Alat, jika lahan melebihi 5000 m² $^{2}$ maka diperlukan Surat Izin Penunjukan Penggunaan Tanah dan Surat Perjanjian Pemenuhan Kewajiban Surat Izin Penunjukan Penggunaan Tanah, lalu juga pengembang harus mempunyai Surat Pernyataan bermaterai telah membuat SRAH. Selain itu pengembang harus menyerahkan dokumen proyek yaitu Izin Mendirikan Bangunan beserta gambar lampiran arsitektur, Izin Pelaku Teknis Bangunan (IPTB) bidang arsitektur dan konstruksi, seperti Instalasi Arus Kuat (LAK), Instalasi Arus 
Lemah (LAL), Sanitasi Drainase Pemipaan (SDP), Transportasi Dalam Gedung(TDG), Tata Udara Gedung(TUG). Lalu As built drawing bangunan gedung yang telah disahkan, Surat Pernyataan Direksi Pengawas atau pengkaji teknis, Laporan Direksi Pengawas oleh pengawas yang mempunyai (IPTB), Laporan Kajian Teknis oleh pengkaji yang mempunyai IPTB, Lembar Pencatatan Laporan Pemeliharaan Bangunan, Sertifikat Keselamatan Kebakaran dari Dinas Tenaga Kerja dan Transmigrasi.

Dijelaskan sebelumnya bahwa salah satu dari persyaratan dari pengurusan Sertifikat Laik Fungsi yaitu adanya Sertifikat Keselamatan Kebakaran dari Dinas Penanggulangan Kebakaran dan Penyelamatan sesuai dengan Pasal 50 Peraturan Daerah DKI Jakarta Nomor 8 Tahun 2008 tentang pencegahan dan penanggulangan bahaya kebakaran. Sertifikat Keselamatan Kebakaran tersebut dapat diberikan jika hasil data pemeriksaan di lapangan mengatakan bahwa bangunan tersebut telah memenuhi beberapa hal yaitu adanya akses pemadam kabakaran, terdapatnya sarana penyelamatan jiwa, dilengkap dengan manajemen keselamatan kebakaran gedung, tersedianya sistem proteksi kebakaran yang telah terpasang pada bangunan rumah susun tersebut.

Yang dimaksud dengan Sistem Proteksi Kebakaran adalah sistem untuk melindungi atau mengamankan bangunan gedung dari kebakaran. Sistem Proteksi Kebakaran terbagi menjadi 2, yaitu proteksi pasif dan proteksi aktif.

Proteksi pasif adalah sistem perlindungan terhadap kebakaran yang dilaksanakan dengan melakukan pengaturan komponen bangunan gedung dari aspek arsitektur dan struktur sedemikian rupa sehingga dapat melindungi penghuni dan benda dari kerusakan fisik saat terjadi kebakaran. Lebih lanjut dijelaskan bahwa fungsi dari proteksi pasif tersebut ialah untuk mencegah dan membatasi penyebaran kebakaran, asap, dan keruntuhan sehingga penghuni memiliki cukup waktu untuk melakukan evakuasi secara aman tanpa dihalangi oleh penyebaran api dan asap kebakaran, dan juga memberikan peluang kepada petugas pemadam kebakaran untuk beroperasi. Proteksi pasif tersebut meliputi beberapa hal, yaitu bahan bangunan 
gedung, konstruksi bangunan gedung, kompartemenisasi dan pemisahan, penutup Bukaan.

Sedangkan proteksi aktif adalah sistem perlindungan terhadap kebakaran yang dilaksanakan dengan menggunakan peralatan yang dapat bekerja secara otomatis maupun manual, digunakan oleh penghuni atau petugas pemadam kebakaran dalam melaksanakan operasi pemadaman, selain itu sistem itu digunakan dalam melaksanakan penanggulangan awal kebakaran, yang meliputi Alat Pemadam Api Ringan, Sistem Deteksi dan Alarm Kebakaran, Sistem Pipa Tegak dan Selang Kebakaran serta Hidran, Sistem Sprinkler Otomatis, Sistem Pengendalian Asap, lift Kebakaran, Pencahayaan Darurat, Penunjuk Arah Darurat, Sistem Pasokan Daya Listrik Darurat, Pusat Pengendali Kebakaran, Instalasi Pemadaman Khusus.

Apartemen Parama tidak memenuhi beberapa persyaratan yang telah diatur di dalam Peraturan Daerah DKI Jakarta Nomor 8 Tahun 2008 tentang pencegahan dan penanggulangan bahaya kebakaran. Adapun beberapa hal yang dinilai tidak memenuhi persyaratan, yaitu tidak memperbaharui perangkat kelistrikannya dengan produk baru, tidak melengkapi bangunannya dengan Alat Pemadam Kebakaran Ringan yang memadai, Sistem Deteksi dan Alarm Kebakaran yang tidak berfungsi, dan Sistem Pasokan Daya Listrik Darurat yang tidak tersedia.

Dengan tidak dipenuhinya persyaratan tersebut, maka Sertifikat Keselamatan Kebakaran tidak dapat dikeluarkan. Adanya Sertifikat Keselamatan Kebakaran tersebut yang akan memenuhi aspek keselamatan yang menjadi salah satu parameter dari laiknya fungsi suatu bangunan. Jika bangunan tersebut dinyatakan laik fungsi dengan memenuhi segala aspek yang menjadi parameternya, maka Sertifikat Laik Fungsi akan diterbitkan. Dengan adanya Sertifikat Laik Fungsi, bangunan apartemen tersebut dapat difungsikan sebagaimana mestinya.

Namun, Apartemen Parama difungsikan menjadi sebuah hunian sebelum gedung apartemen tersebut dilengkapi dengan Sertifikat Laik Fungsi. Oleh karena adanya perbuatan tersebut yang membuat unsur-unsur dari Perbuatan Melawan 
Hukum, yaitu "adanya perbuatan" dan "adanya hal yang bertentangan dengan hukum" menjadi terpenuhi.

Adapun fakta hukum yang memenuhi unsur Perbuatan Melawan Hukum lainnya yaitu "adanya kesalahan" dimana terdapat penyegelan di apartemen tersebut sebelum gedung apartemen terbakar. Adanya penyegelan tersebut diharapkan agar pihak apartemen secepatnya memenuhi kewajibannya memenuhi persyaratan laik fungsi bangunannya. Namun penyegelan itu tidak dihiraukan oleh pihak apartemen sampai terbakarnya gedung Apartemen Parama. Kebakaran tersebut memunculkan kerugian yang diderita oleh berbagai pihak. Dengan itu, unsur dari Perbuatan Melawan Hukum yaitu "adanya kerugian yang diderita" terpenuhi.

Berbicara mengenai kerugian yang timbul akibat Perbuatan Melawan Hukum adalah rugi "scade", di mana bentuk kerugian dalam konteks Perbuatan Melawan Hukum berbeda dengan bentuk kerugian dalam konteks Wanprestasi. Di dalam konteks Wanprestasi, sebagaimana tertuang di dalam Pasal 1246 Kitab UndangUndang Hukum Perdata, bentuk kerugian yang dimaksud yaitu berupa biaya, kerugian, dan bunga.

Biaya adalah segala pengeluaran atau ongkos yang secara nyata sudah dikeluarkan oleh salah satu pihak. Rugi adalah kerugian karena kerusakan barangbarang yang dipunyai kreditur karena kelalaian dari debitur. Sedangkan bunga adalah sesuatu yang diharapkan menjadi keuntungan atas akibat kelalaian debitur, namun jika mengacu pada ketentuan Pasal 1250 Kitab Undang-Undang Hukum Perdata, batas maksimal bunga tidak boleh melebihi 6\% per tahun.

Dalam gugatan Perbuatan Melawan Hukum, tidak ada ketentuan yang mengatur mengenai bentuk ganti rugi berupa biaya, kerugian, bunga, sebagaimana hal tersebut dikenal dalam gugatan Wanprestasi. Bentuk kerugian di dalam konteks Perbuatan Melawan Hukum menurut Kitab Undang-Undang Hukum Perdata ialah bahwa seseorang yang dirugikan tersebut dapat menggugat pelaku yang menimbulkan kerugian tersebut untuk menggantikan kerugian yang nyata telah dideritanya atau 
yang disebut dengan kerugian materil, dan juga keuntungan yang akan diperoleh di kemudian hari atau yang disebut dengan kerugian immateril.

Berdasarkan Pasal 1371 ayat (2) Kitab Undang-Undang Hukum Perdata tersirat pedoman yang menyatakan penggantian kerugian dinilai dari kedudukan dan kemampuan kedua belah pihak, dan menurut keadaan. Di dalam Pasal 1372 ayat (2) Kitab Undang-Undang Hukum Perdata mengatakan bahwa Hakim yang akan menilai suatu kerugian tersebut dimana Hakim tersebut harus memperhatikan keadaan dan berat ringannya kemampuan kedua belah pihak.

Dalam kasus ini, akibat dari kebakaran pada Apartemen Parama yang harus dipertimbangkan Hakim jika penggugat mengajukan gugatannya ke Pengadilan, dan jika musyawarah tidak mencapai mufakat, adalah munculnya kerugian yang diderita oleh penghuni satuan unit rumah susun yang harus ditanggung pengembang dari apartemen tersebut yang berupa pengembalian uang sewa yang telah dibayarkan pada saat awal terjadinya sewa-menyewa, dan menanggung biaya rumah sakit semasa perawatan pasa saat dan pasca kebakaran.

Selain gugatan ganti rugi secara perdata, pengembang dapat dimintakan pertanggungjawaban atas perbuatannya secara pidana. Hal tersebut dimungkinkan, sebab di dalam Pasal 283 ayat (2) Peraturan Daerah Provinsi Daerah Khusus Ibukota Jakarta Nomor 7 Tahun 2010 tentang Bangunan Gedung dikatakan bahwa "setiap pemilik bangunan gedung, pengguna bangunan gedung, penyedia jasa konstruksi bangunan gedung yang melanggar ketentuan Pasal 13 ayat (3), Pasal 15 ayat (1), Pasal 124 ayat (3), 183 ayat (1), Pasal 186 ayat (4), Pasal 188 ayat (1), Pasal 191, Pasal 192, Pasal 195, Pasal 231 ayat (1), Pasal 237 ayat (1), dan Pasal 245 ayat (1) dipidana dengan pidana kurungan paling lama 6 (enam) bulan atau denda paling banyak Rp.50.000.000 (lima puluh juta rupiah). Pasal yang mengatur mengenai adanya kewajiban memenuhi Sertifikat Laik Fungsi sebelum penggunannya ialah Pasal 237 ayat (1) Peraturan Daerah Provinsi Daerah Khusus Ibukota Jakarta Nomor 7 Tahun 2010 tentang Bangunan Gedung. 
Menyinggung sedikit mengenai hak dari penghuni selaku konsumen, bahwa hak-haknya tersebut diatur di dalam Perjanjian Pengikatan Jual Beli, namun tetap harus mengacu kepada Undang-Undang Nomor 8 Tahun 1999 tentang Perlindungan Konsumen. Menurut Pasal 1 angka 1 Undang-Undang Nomor 8 Tahun 1999 tentang Perlindungan Konsumen, pengertian mengenai Perlindungan Konsumen merupakan upaya yang menjamin adanya kepastian hukum untuk memberikan perlindungan kepada konsumen sehingga dapat melahirkan rasa aman kepada pihak yang bersangkutan, yaitu konsumen dan pelaku usaha. Pengertian mengenai konsumen juga dijelaskan di dalam Pasal 1 angka 1 Undang-Undang Nomor 8 Tahun 1999 tentang Perlindungan Konsumen, yaitu setiap orang pemakai barang dan/atau jasa yang tersedia dalam masyarakat, baik bagi kepentingan sendiri, keluarga, orang lain maupun makhluk hidup lain dan untuk tidak diperdagangkan. Konsumen dalam konteks transaksi jual-beli rumah susun ialah pembeli barang yang berupa satuan unit rumah susun, dan juga penghuni yang menempati satuan unit rumah susun, baik sebagai pemilik maupun bukan pemilik (penyewa).

Undang-Undang Nomor 8 Tahun 1999 tentang Perlindungan Konsumen mengatur mengenai hak dan kewajiban dari konsumen, yaitu hak atas kenyamanan, keamanan, dan keselamatan dalam mengkomsumsi barang dan/atau jasa, hak untuk memilih barang dan/atau jasa serta mendapatkan barang dan/atau jasa tersebut sesuai dengan nilai tukar dan kondisi serta jaminan yang dijanjikan, hak atas informasi yang benar, jelas, dan jujur mengenai kondisi dan jaminan barang dan/atau jasa, hak untuk didengar pendapat dan keluhannya atas barang dan/atau jasa yang digunakan, hak untuk mendapatkan advokasi, perlindungan, dan upaya penyelesaian sengketa perlindungan konsumen secara patut, hak untuk diperlakukan atau dilayani secara benar dan jujur serta tidak diskriminatif, hak untuk mendapatkan kompensasi, ganti rugi dan/atau penggantian apabila barang dan/atau jasa yang diterima tidak sesuai dengan perjanjian atau tidak sebagaimana mestinya, hak-hak yang diatur dalam ketentuan peraturan perundang-undangan lainnya. 
Jika pihak pelaku usaha dalam hal ini pengembang melanggar hak seseorang lainnya yaitu penghuni dimana pelanggaran tersebut menimbulkan kerugian yang diderita oleh seseorang lainnya tersebut, maka selain melalui pengadilan, para pihak juga dapat menyelesaikan perkaranya tersebut ke Badan Penyelesaian Sengketa Konsumen.

\section{Penutup}

\section{A. Kesimpulan}

Kesimpulan yang dapat diambil dari penulisan yang telah disusun di atas ialah bahwa setiap bangunan gedung termasuk rumah susun harus memenuhi aspek keandalan teknis yang meliputi segi keselamatan, kesehatan, kenyamanan, dan kemudahan. Hal tersebut lah yang menjadi parameter dari laik fungsinya suatu bangunan, di mana jika telah dipenuhi maka Sertifikat Laik Fungsi dapat diterbitkan. Dengan adanya Sertifikat Laik Fungsi tersebut, rumah susun tersebut akan diakui dan terjamin keandalannya, agar penghuni merasa aman menempati satuan unit rumah susunnya.

Pemerintah terus berupaya untuk menciptakan bangunan gedung yang laik fungsi. Bentuk dari upayanya tersebut diwujudkan ke dalam suatu ketentuan yang mewajibkan seluruh pengembang harus memiliki Sertifikat Laik Fungsi sebelum pemanfaatannya. Ketentuan tersebut dituangkan ke dalam Undang-Undang Nomor 28 Tahun 2002 Tentang Bangunan Gedung, yang dimana mengenai rumah susun diatur secara khusus di dalam Undang-Undang Nomor 20 Tahun 2011 tentang Rumah Susun.

Sebagaimana telah disinggung sebelumnya, segi keselamatan merupakan salah satu parameter laik fungsinya suatu bangunan. Adapun yang dimaksud dengan segi keselamatan tersebut meliputi kemampuan bangunan gedung dalam mencegah dan menanggulangi bahaya kebakaran melalui sistem proteksi kebakaran yaitu proteksi pasif dan/atau proteksi aktif di mana hal tersebut diatur di dalam Peraturan Daerah DKI Jakarta Nomor 8 Tahun 2008 tentang pencegahan dan penanggulangan bahaya 
kebakaran. Di dalam peraturan daerah tersebut dikatakan bahwa apabila bangunan rumah susun telah memenuhi persyaratan yang telah ditentukan, dimana salah satunya ialah persyaratan terkait sistem proteksi kebakaran, maka Dinas Penanggulangan Kebakaran dan Penyelamatan akan memberikan Sertifikat Keselamatan Kebakaran, dimana sertifikat tersebut juga merupakan persyaratan dalam pengurusan Sertifikat Laik Fungsi.

PT. Mahakam Indomakmur selaku pengembang dari Apartemen Parama tersebut dinilai tidak memenuhi persyaratan terkait sistem proteksi. Dengan tidak dipenuhi persyaratan terkait sistem proteksi tersebut, maka Sertifikat Keselamatan Kebakaran tidak dapat dikeluarkan. Hal tersebut memiliki implikasi kepada penerbitan Sertifikat Laik Fungsi. Secara normatif, bangunan gedung yang tidak memiliki Sertifikat Laik Fungsi, tidak dapat dimanfaatkan. Namun PT. Mahakam Indomakmur melakukan perbuatan yang melawan undang-undang dengan menggunakan bangunan gedung Apartemen Parama yang tidak laik fungsi tersebut sebagai tempat tinggal. Oleh karena apartemen tersebut tidak memenuhi kelaikan fungsi, hal ini lah yang menimbulkan kebakaran. Dengan adanya perbuatan tersebut maka pengembang dapat dimintakan pertanggungjawabannya baik secara perdata maupun pidana.

Dasar dari pembebanan suatu tanggung jawab secara perdata yaitu adanya pemenuhan semua unsur yang terkandung di dalam suatu Perbuatan Melawan Hukum yang diatur di dalam Kitab Undang-Undang Hukum Perdata, sehingga sanksi secara perdata tersebut dapat dikenakan kepadanya. Selain itu, pemidanaan tersebut dapat dijatuhkan kepadanya, sebab perbuatannya tersebut diatur di dalam Peraturan Daerah Provinsi Daerah Khusus Ibukota Jakarta Nomor 7 Tahun 2010 tentang Bangunan Gedung. Adapun bentuk dari pertanggungjawaban secara pidana tersebut yaitu pidana kurungan selama 6 (enam) bulan atau denda paling banyak Rp. 50.000 .000 (lima puluh juta rupiah).

Perihal hak dari penghuni tersebut diatur di dalam Perjanjian Pengikatan Jual Beli yang tetap harus mengacu kepada Undang-Undang Nomor 8 Tahun 1999 tentang 
Perlindungan Konsumen. Adapun hak dari penghuni tersebut, yaitu hak atas kenyamanan, keamanan, dan keselamatan dalam mengkomsumsi barang dan/atau jasa, hak untuk memilih barang dan/atau jasa serta mendapatkan barang dan/atau jasa tersebut sesuai dengan nilai tukar dan kondisi serta jaminan yang dijanjikan, hak atas informasi yang benar, jelas, dan jujur mengenai kondisi dan jaminan barang dan/atau jasa, hak untuk didengar pendapat dan keluhannya atas barang dan/atau jasa yang digunakan, hak untuk mendapatkan advokasi, perlindungan, dan upaya penyelesaian sengketa perlindungan konsumen secara patut, hak untuk diperlakukan atau dilayani secara benar dan jujur serta tidak diskriminatif, hak untuk mendapatkan kompensasi, ganti rugi dan/atau penggantian apabila barang dan/atau jasa yang diterima tidak sesuai dengan perjanjian atau tidak sebagaimana mestinya, hak-hak yang diatur dalam ketentuan peraturan perundang-undangan lainnya.

Jika pihak pelaku usaha dalam hal ini pengembang melanggar hak seseorang lainnya yaitu penghuni dimana pelanggaran tersebut menimbulkan kerugian yang diderita oleh seseorang lainnya tersebut, maka selain melalui pengadilan, para pihak juga dapat menyelesaikan perkaranya tersebut ke Badan Penyelesaian Sengketa Konsumen.

\section{B. Saran}

Berdasarkan hasil penelitian yang dilakukan terkait ketiadaan Sertifikat Laik Fungsi, maka berikut merupakan saran yang dapat disampaikan kepada pemerintah DKI Jakarta yaitu melakukan pendataan seluruh bangunan gedung di wilayah DKI Jakarta guna mengetahui jumlah bangunan gedung yang tidak memiliki Sertifikat Laik Fungsi. Bagi bangunan gedung khususnya rumah susun yang tidak memiliki Sertifikat Laik Fungsi diberikan sanksi tegas agar memberikan efek jera kepada pengembang. Adanya efek jera tersebut diharapkan pengembang dapat dengan segera melengkapi kewajibannya menurut undang-undang. 


\section{Daftar Pustaka}

\section{A. Buku}

Pendidikan Nasional. Departemen. Kamus Besar Bahasa Indonesia. (Jakarta: PT Gramedia Pustaka Utama, 2012)

Sabaruddin, Arif. Persyaratan Teknis Bangunan. (Jakarta: Griya Kreasi, 2013)

Sutedi, Adrian. Hukum Rumah Susun\&Apartemen. (Jakarta: Sinar Grafika, 2012)

Setiawan, I Ketut Oka. Hukum Perikatan. (Jakarta: Sinar Grafika, 2016)

Santoso, Urip. Hukum Perumahan. (Jakarta: Prenadamedia Group, 2014)

Soekanto, Soerjono. Pengantar Penelitian Hukum. (Jakarta: UI Press, 2010)

Marzuki, Peter Mahmud. Penelitian Hukum. (Jakarta: Prenadamedia Group, 2005)

Arifin, Zaenal. Metode Penulisan Ilmiah. (Jakarta: Pustaka Mandiri, 2002)

Harsono, Boedi. Hukum Agraria Indonesia. (Jakarta: Djambatan, 2003)

Santoso, Urip. Hukum Agraria \& Hak-Hak Atas Tanah, (Jakarta: Kencana, 2009)

\section{B. Jurnal}

Harsono, Boedi. "Catatan Mengenai Hukum Yang Berlaku Sekarang Ini Terhadap Bangunan dan Pemilikan Bangunan”. Jurnal Hukum dan Pembangunan

\section{Peraturan}

Indonesia. Kitab Undang-undang Hukum Perdata

Indonesia. Undang-Undang Nomor 28 Tahun 2002 Tentang Bangunan Gedung

Indonesia. Undang-undang Nomor 20 Tahun 2011 tentang Rumah Susun

Indonesia. Peraturan Menteri Pekerjaan Umum Nomor 25 Tahun 2007 tentang Pedoman Sertifikat Laik Fungsi Bangunan Gedung

Indonesia. Peraturan Daerah Provinsi Daerah Khusus Ibukota Jakarta Nomor 7 Tahun 2010 tentang Bangunan Gedung

Indonesia. Peraturan Daerah Provinsi Daerah Khusus Ibukota Jakarta Nomor 8 Tahun 2008 tentang Pencegahan dan Penanggulangan Bahaya Kebakaran

\section{Internet}

Anonim, "Hak dan Kewajiban Para Pihak Dalam Transaksi Rumah Susun. ”http://erwinkallonews.com/2018/04/04/hak-dan-kewajiban-para-pihakdalam-transaksi-rumah-susun-bagian-1/. Diakses tanggal 4 April 2018.

Christian Samuel, "Pedoman Pengikatan Jual Beli Rumah Berdasarkan Kepmenpera Nomor 09 KPTSM Tahun 1995."https://www.hukumproperti.com/rangkumanperaturan/pedoman-pengikatan-jual-beli-rumah-berdasarkan-kepmenperanomor-09kptsm1995-tahun-1995/. Diakses tanggal 4 April 2018. 